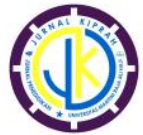

http://ojs.umrah.ac.id/index.php/kiprah

\title{
Pengembangan Bahan Ajar Menulis Feature Berdasarkan Hasil Analisis Kebutuhan Belajar Mahasiswa Program Jurnalistik di Universitas Negeri Malang
}

\author{
Degita Danur Suharsono* \\ Bahasa, Komunikasi, dan Pariwisata, Politeknik Negeri Jember, Kabupaten Jember, Indonesia \\ Pengiriman: 05/02/2020; Diterima: 08/05/2020; Publikasi: 30/06/2020 \\ DOI: https://doi.org/10.31629/kiprah.v8i1.1968
}

\begin{abstract}
Abstrak
Program keahlian jurnalistik merupakan paket mata kuliah pilihan yang ada di Jurusan Sastra Indonesia, Universitas Negeri Malang. Menulis feature merupakan salah satu pembelajaran yang terdapat dalam paket mata kuliah pilihan jurnalistik. Pengembangan bahan ajar menulis feature meliputi aspek materi pembelajaran, sistematika penyajian bahan ajar, penggunaan bahasa dalam bahan ajar, dan organisasi tampilan bahan ajar. Penelitian ini bertujuan untuk mengembangkan bahan ajar menulis feature berdasarkan hasil analisis kebutuhan belajar mahasiswa program jurnalistik di Universitas Negeri Malang. Penelitian ini termasuk dalam model penelitian pengembangan. Teknik pengumpulan data menggunakan metode wawancara dan angket. Instrumen pengumpulan data yang digunakan dalam penelitian pengembangan ini meliputi pedoman wawancara, angket prapengembangan, dan angket uji coba produk. Berdasarkan hasil pengembangan, bahan ajar menulis feature untuk mahasiswa program jurnalistik layak untuk diimplementasikan sesuai penilaian, saran, dan hasil revisi dari validator.
\end{abstract}

Kata kunci: bahan ajar; menulis feature; mahasiswa program jurnalistik

\begin{abstract}
This research aimed to develop teaching materials for writing features based on the analysis of the learning needs of journalism program students at Malang State University. The journalistic expertise program is an optional course in The Indonesian Literature Department, State University of Malang. Writing feature is one of the lessons in journalistic optional course. Development writing feature in teaching materials included aspects of learning materials, systematic presentation of teaching materials, usage of language in teaching materials, and display organization of teaching materials. This study is included in the development research model. Data collection techniques used interview and questionnaire methods. In this development study, Data collection instruments used interview guidelines, pre-development questionnaires, and product trial questionnaires. Based on the results of the development study, teaching materials of writing feature for journalism program students' university are valid to be implemented.
\end{abstract}

Keywords: teaching material; writing feature; journalism program students' university

\section{PENDAHULUAN}

Salah satu ragam tulisan jurnalistik adalah feature. Feature merupakan jenis penulisan dalam surat kabar yang bukan berita, reportase, atau tulisan lain seperti tajuk rencana, kolom, atau artikel opini (Barus, 2010). Feature termasuk dalam kategori tulisan kreatif dengan gaya penulisan fiksi, tidak pernah basi, dan human interest.

Di Jurusan Sastra Indonesia, Fakultas Sastra, Universitas Negeri Malang, feature diintegrasikan dalam paket mata kuliah keahlian berkarya pilihan. Kurikulum Program Studi S1 Pendidikan Bahasa, Sastra Indonesia,

*Email Korespondensi : danur@polije.ac.id 
dan Daerah (PS PBSID) dan Program Studi Bahasa dan Sastra Indonesia (PS BSI), setiap mahasiswa diwajibkan menempuh satu paket mata kuliah keahlian berkarya pilihan. Salah satu paket mata kuliah keahlian berkarya pilihan adalah paket mata kuliah jurnalistik. Paket mata kuliah jurnalistik terdiri atas 15 SKS (sistem kredit semester) meliputi mata kuliah Pengantar Jurnalistik, Menulis Berita dan Feature, Menulis Editorial dan Opini, Keredaksian, dan Teknologi Informasi untuk Jurnalistik.

Mata kuliah Menulis berita dan Feature bertujuan untuk meningkatkan kompetensi mahasiswa agar mampu menulis berita dan feature pada berbagai media massa. Materi perkuliahannya meliputi karakteristik berita dan feature, komponen berita dan feature, pengumpulan bahan penulisan, teknik dan prosedur penulisan berita dan feature. Upaya untuk mencapai tujuan kompetensi tersebut adalah membuat bahan ajar yang dikhususkan untuk mahasiswa program jurnalistik.

Bahan ajar digunakan untuk membantu kegiatan perkuliahan Menulis Berita dan Feature. Bahan ajar mata kuliah Menulis Berita dan Feature sebelumnya pernah dikembangkan oleh Moch. Syahri, S. Sos., M. Si., (dosen Jurusan Sastra Indonesia, Fakultas Sastra, Universitas Negeri Malang) berjudul Diktat Matakuliah Berita. Bahan ajar tersebut berisikan materi menulis berita untuk mahasiswa program jurnalistik. Namun, dalam bahan ajar tersebut, materi mengenai menulis feature dibahas sekilas dan kurang mendalam.

Analisis kebutuhan belajar mahasiswa program jurnalistik dilakukan sebagai landasan pengembangan bahan ajar. Ada dua kegiatan untuk mengetahui kebutuhan belajar mahasiswa, yakni penyebaran angket analisis kebutuhan dan wawancara dengan dosen pengampu mata kuliah. Berdasarkan hasil penyebaran angket analisis kebutuhan, 87\% mahasiswa membutuhkan bahan ajar menulis feature. Hasil wawancara dengan dosen pengampu mata kuliah diketahui bahwa bahan ajar yang dikembangkan berupa panduan menulis feature dan berisikan materi penulisan feature tingkat dasar.

Dengan demikian, perlu dikembangkan sebuah bahan ajar menulis feature untuk mahasiswa program jurnalistik yang efektif dan dapat membantu mahasiswa dalam pembelajaran menulis feature. Bahan ajar berisikan materi pembelajaran terkait dengan kompetensi yang wajib dikuasai oleh mahasiswa. Bahan ajar yang dikembangkan juga memerhatikan sistematika penyajian, penggunaan bahasa, dan organisasi tampilan.

Penelitian tentang pengembangan bahan ajar menulis feature untuk mahasiswa program keahlian jurnalistik di Jurusan Sastra Indonesia, Fakultas Sastra, Universitas Negeri Malang perlu dikembangkan. Ada tiga penelitian mengenai feature yang pernah dilakukan Dyah (2009); Nuryani (2010); dan Yusufrani, Nursih, \& Prasetya (2013). Fokus penelitian Dyah berupa gaya bahasa tulisan feature dalam surat kabar Jawa Pos. Penelitian Nuryani berupa pemanfaatan media feature bertema "bencana alam" untuk pembelajaran menulis puisi siswa kelas IX Program Bahasa Madrasah Aliyah Negeri Malang II Batu. Penelitian Yusufrani, Nursih, dan Prasetya bertujuan untuk melihat gaya bahasa tulisan feature pada Koran Radar Banten berdasarkan elemen semantik, sintaksis, stilistik, dan retoris. Ketiga penelitian tersebut berfokus pada analisis tulisan dan pemanfaatan feature sebagai media pembelajaran, sedangkan penelitian pengembangan yang dilakukan berfokus pada pengembangan bahan ajar menulis feature berdasarkan hasil analisis kebutuhan mahasiswa program jurnalistik.

Pengembangan bahan ajar diharapkan dapat membantu mahasiswa dalam pembelajaran menulis feature. Penyusunan bahan ajar disesuaikan kebutuhan mahasiswa dan dosen. Penelitian ini bertujuan mengembangkan bahan ajar menulis feature berdasarkan hasil analisis kebutuhan untuk mahasiswa program jurnalistik berdasarkan aspek materi pembelajaran, sistematika penyajian, penggunaan bahasa dalam bahan ajar, dan tampilan bahan ajar. 


\section{METODE PENELITIAN}

Penelitian ini merupakan penelitian pengembangan. Model penelitian pengembangan yang digunakan adalah hasil adaptasi rancangan model penelitian pengembangan Sukmadinata (2008). Penelitian pengembangan ini diawali dengan kegiatan studi pendahuluan yang difokuskan pada analisis kebutuhan mahasiswa dan dosen dalam pembelajaran menulis feature. Langkah berikutnya adalah pemetaan domain pembelajaran meliputi tujuan pembelajaran, materi pembelajaran, dan latihan. Hasil analisis kebutuhan belajar tersebut digunakan sebagai acuan tahap berikutnya, yakni pengembangan bahan ajar.

Tahap pengembangan berupa pembuatan produk yang meliputi pengembangan materi pembelajaran menulis feature, sistematika penyajian, penggunaan bahasa, dan organisasi tampilan. Pada tahap pengembangan materi pembelajaran menulis feature, peneliti mempertimbangkan kriteria kedalaman materi, kelengkapan materi, variasi materi, kreativitas materi, dan latihan praktik. Pengembangan sistematika penyajian materi, peneliti mempertimbangkan kriteria keruntutan dan kelengkapan. Pengembangan penggunaan bahasa bahan ajar, peneliti mempertimbangkan kriteria gaya komunikatif dan kaidah penulisan. Pengembangan tampilan bahan ajar, peneliti mempertimbangkan kriteria tata letak, organisasi desain tampilan, dan pemilihan font.

Tahap pengujian berupa uji coba bahan ajar yang meliputi kegiatan validasi ahli bahan ajar, validasi ahli materi pembelajaran, validasi praktisi, dan revisi produk. Peneliti menggunakan kriteria penilaian kesesuaian, kelengkapan, sistematika penyajian, tampilan, penggunaan bahasa, dan kemudahan penggunaan pada validasi ahli bahan ajar. Pada validasi ahli materi, peneliti menggunakan kriteria penilaian kedalaman materi, keakuratan materi, kelengkapan materi, sistematika penyajian, dan penggunaan bahasa. Dalam validasi praktisi, peneliti menggunakan kriteria penilaian materi pembelajaran, ketepatan, kelengkapan, sistematika penyajian, kebermanfaatan, kemudahan penggunaan, dan penggunaan bahasa. Prosedur yang ditempuh dalam revisi produk meliputi memahami hasil validasi, pengambilan kesimpulan, serta perbaikan produk mengacu pada hasil validasi ahli dan praktisi.

Subjek penelitian pengembangan ini terdiri atas subjek yang digunakan pada analisis kebutuhan belajar mahasiswa program jurnalistik dan subjek yang digunakan pada uji coba produk. Subjek penelitian untuk analisis kebutuhan belajar adalah mahasiswa dan dosen program jurnalistik, Jurusan Sastra Indonesia, Fakultas Sastra, Universitas Negeri Malang. Subjek uji coba produk adalah ahli bahan ajar, ahli materi, dan praktisi yang berpengalaman.

Data penelitian pengembangan ini meliputi data verbal tentang kebutuhan belajar, data verbal tentang pemetaan domain pembelajaran, dan data verbal tentang hasil uji coba produk. Data verbal tentang kebutuhan belajar bersumber dari hasil observasi, hasil penyebaran angket, dan hasil wawancara dengan dosen. Data verbal tentang domain pembelajaran berupa tujuan pembelajaran, materi pembelajaran, dan latihan yang bersumber dari hasil telaah dokumen. Data verbal tentang hasil uji coba produk bersumber dari saran, kritik, serta komentar dari ahli dan praktisi

Peneliti adalah instrumen kunci dalam penelitian ini. Peneliti menggunakan panduan wawancara, panduan observasi, panduan telaah dokumen, angket, dan lembar penilaian produk untuk mengumpulkan data. Data verbal berupa kebutuhan belajar mahasiswa dan pemetaan domain digunakan sebagai acuan pembuatan produk. Data verbal hasil uji coba produk digunakan sebagai revisi produk. Data tersebut dianalisis menggunakan teknik kualitatif meliputi reduksi data, penyajian data, verifikasi, dan kesimpulan. 
HASIL DAN PEMBAHASAN

Faktor penunjang keberhasilan proses pembelajaran adalah bahan ajar yang baik dan berkualitas. Keberadaan bahan ajar dalam lingkup perguruan tinggi dapat digunakan sebagai pegangan dan panduan bagi dosen ketika mengajar. Hal tersebut sesuai dengan definisi bahan ajar menurut Departemen Pendidikan Nasional (2008), yaitu segala bentuk bahan yang digunakan untuk membantu dosen dan mahasiswa dalam pelaksanaan kegiatan belajar di kelas. Selain itu, bahan ajar juga dapat menjadi bahan belajar secara mandiri bagi mahasiswa maupun dengan bimbingan dosen di kelas.

Ada empat aspek yang memengaruhi baik dan tidaknya suatu bahan ajar. Aspekaspek tersebut meliputi bahan ajar memiliki manfaat bagi pebelajar untuk mendapatkan hasil yang spesifik; bahan ajar dapat memotivasi dan membangkitkan minat pebelajar dalam pembelajaran; bahan ajar berisikan materi yang sesuai dengan tingkatan atau level pebelajar yang dituju; dan bahan ajar dapat memfasilitasi kebutuhan pebelajar dalam tujuan untuk mencapai kompetensi pembelajaran yang diharapkan.

Bahan ajar yang baik berisikan tujuan instruksional, materi pembelajaran, dan evaluasi pembelajaran. Hal ini ditujukan agar tercapainya kompetensi pembelajaran yang diharapkan. Senada dengan pendapat tersebut, Widodo \& Jasmadi menyatakan bahan ajar adalah seperangkat sarana atau alat pembelajaran yang berisikan materi pembelajaran, metode, batasan-batasan, dan cara mengevaluasi yang didesain secara sistematis dan menarik dalam rangka mencapai tujuan yang diharapkan, yaitu mencapai kompetensi atau subkompetensi dengan segala kompleksnya (Lestari, 2013). Tujuan instruksional menjelaskan kompetensi yang dicapai setelah mempelajari bahan ajar. Materi pembelajaran berisi materi yang dipelajari dalam bahan ajar. Evaluasi pembelajaran berisi latihan dan pedoman penilaian.
Pengembangan bahan ajar ditujukan untuk pemecahan masalah pembelajaran menulis feature. Pengembangan bahan ajar bukan hanya didasarkan atas kepentingan pengembang, melainkan alternatif pemecahan masalah pembelajaran (Syahid, 2003). Pengembangan bahan ajar ini ditujukan untuk pemecahan masalah yang ada pada mata kuliah menulis berita dan feature, yaitu belum tersedianya bahan ajar khusus untuk pembelajaran menulis feature.

Bahan ajar ini dapat digunakan sebagai salah satu alternatif bahan pengajaran untuk matakuliah menulis berita dan feature, khususnya pembelajaran menulis feature. Bahan ajar ini disusun untuk memenuhi kebutuhan mahasiswa akan adanya bahan ajar dalam kegiatan belajar di kelas. Pengembangan bahan ajar ini adalah upaya menyediakan bahan ajar menulis feature untuk mata kuliah menulis berita dan feature, khususnya pembelajaran menulis feature.

Bahan ajar yang dikembangkan terdiri atas sembilan komponen. Komponenkomponen tersebut meliputi judul, petunjuk belajar untuk mahasiswa dan dosen, tujuan pembelajaran, tujuan pembelajaran, teori, contoh, soal dan latihan praktik, penilaian, dan sumber pustaka. Hal tersebut sesuai dengan pendapat Mbulu (2004) dan Departemen Pendidikan Nasional (2008). Penyusunan bahan ajar harus memuat teori, istilah, persamaan, contoh soal dan contoh praktik, tugas-tugas latihan, pertanyaan dan soal-soal latihan, jawaban dan penyelesaian tugas-tugas, penjelasan mengenai sasaran belajar dan contoh ujian, petunjuk tentang bahan yang dianggap diketahui, sumber pustaka, dan petunjuk belajar (Mbulu, 2004). Departemen Pendidikan Nasional, (2008) menyatakan cakupan bahan ajar meliputi judul, MP (Mata Pelajaran), SK (Standar Kompetensi), KD (Kompetensi Dasar), indikator, petunjuk belajar (untuk mahasiswa dan dosen), tujuan yang akan dicapai, informasi pendukung, latihan-latihan, petunjuk kerja, dan penilaian.

Produk bahan ajar yang telah direvisi meliputi aspek deskripsi isi materi 
pembelajaran menulis feature, sistematika penyajian, penggunaan bahasa, dan tampilan bahan ajar. Deskripsi materi pembelajaran dalam bahan ajar disesuaikan dengan kebutuhan mahasiswa program jurnalistik, Jurusan Sastra Indonesia, Fakultas Sastra, Universitas Negeri Malang. Materi pembelajaran dalam bahan ajar ini telah layak untuk digunakan dalam pembelajaran menulis feature. Muslich (2010) berpendapat beberapa kriteria kelayakan materi pembelajaran dalam bahan ajar yang harus dipenuhi bahan ajar, yaitu kesesuaian uraian materi dengan standar kompetensi dan kompetensi dasar yang terdapat dalam kurikulum mata pelajaran yang bersangkutan, keakuratan materi, dan materi pendukung pelajaran.

\section{Materi Pembelajaran Bahan Ajar}

Materi dalam bahan ajar ini meliputi teori, contoh, dan latihan disesuaikan dengan prinsip-prinsip menulis feature. Teori dalam bahan ajar berisi pengertian feature, karakteristik feature, fungsi feature, jenis-jenis feature, bahan penulisan feature, struktur feature, menulis judul feature, menulis titik mangsa feature, menulis teras feature, menulis tubuh feature, dan menulis penutup feature. Pemilihan teori diharapkan dapat mengeksplorasi pengetahuan mahasiswa dalam mencapai kompetensi yang ingin dicapai. Sesuai dengan kompetensi yang wajib dicapai oleh mahasiswa pada mata kuliah menulis berita dan feature, khususnya pembelajaran menulis feature. Kompetensi tersebut meliputi karakteristik berita dan feature, komponen berita dan feature, pengumpulan bahan penulisan, dan teknik dan prosedur penulisan berita dan feature.

Contoh dalam bahan ajar terdiri atas empat macam. Secara visual dapat dilihat pada Gambar 1.

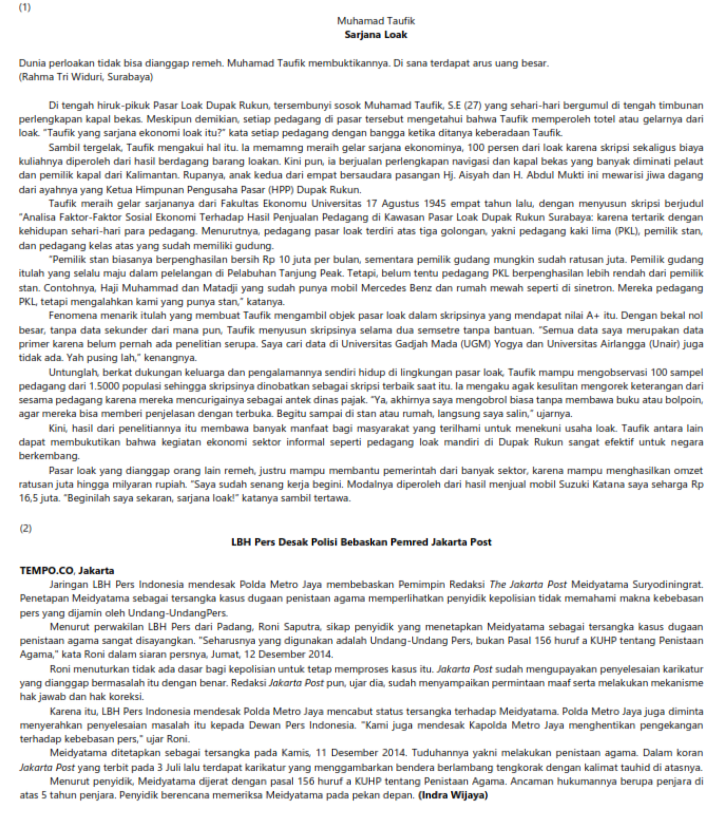

Gambar 1: Contoh Tulisan Feature dan Berita

Pada Gambar 1 diberikan contoh feature dan berita pada awal bab 1 digunakan sebagai model rangsangan mahasiswa untuk membedakan tulisan feature dan berita dari unsur karakteristik feature, fungsi feature, dan struktur tulisa feature.

Selanjutnya terdapat juga pada bab 1 contoh tulisan feature berdasarkan jenisnya, yaitu feature sejarah, feature tokoh, feature pariwisata/perjalanan, feature ilmiah, feature olahraga, feature komunitas, feature anekdot, dan feature advertising. Contoh jenis-jenis feature digunakan untuk membedakan feature menurut jenisnya. Hal ini sesuai dengan hasil analisis kebutuhan belajar, yakni mahasiswa dan dosen membutuhkan contoh-contoh feature berdasarkan jenisnya.

Pada bab 2 terdapat contoh struktur feature digunakan sebagai acuan mahasiswa dalam penulisan feature. Struktur tulisan meliputi bagian anak judul yang berfungsi memperjelas judul feature; judul feature bersifat ringkas, padat, jelas, kreatif, menarik, sesuai dengan isi feature, dan menggunakan gaya bahasa sastra; titik mangsa merupakan pemicu perhatian pembaca dan menjadi pintu masuk dalam tulisan feature; identitas penulis berisi nama penulis dan lokasi peliputan; teras feature berfungsi sebagai penarik minat pembaca dan menggiring pembaca pada 
tulisan berikutnya; tubuh feature berisi inti tulisan feature bersifat kesatuan, hubungan, dan penekanan cerita; penutup feature berisi kesimpulan, saran, kritik, atau memberi kesan kepada pembaca; dan kode tulisan berisi kode identitas penulis, editor, dan sumber berita yang ditulis menggunakan kode. Pemilihan contoh-contoh dalam bahan ajar diharapkan dapat membantu mahasiswa dalam menulis feature. Ada lima struktur yang dikembangkan dalam bahan ajar sebagai pilihan mahasiswa dalam menulis feature. Kelima struktur tersebut dapat dilihat sebagai berikut.

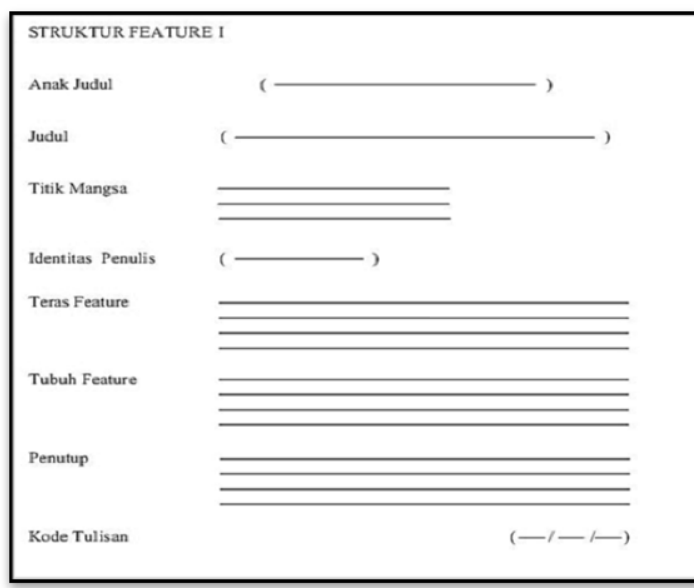

Gambar 2: Struktur Feature I

Pada struktur feature Gambar 2, struktur diawali anak judul, judul, titik mangsa, identitas penulis, teras feature, tubuh feature, penutup, dan kode tulisan.

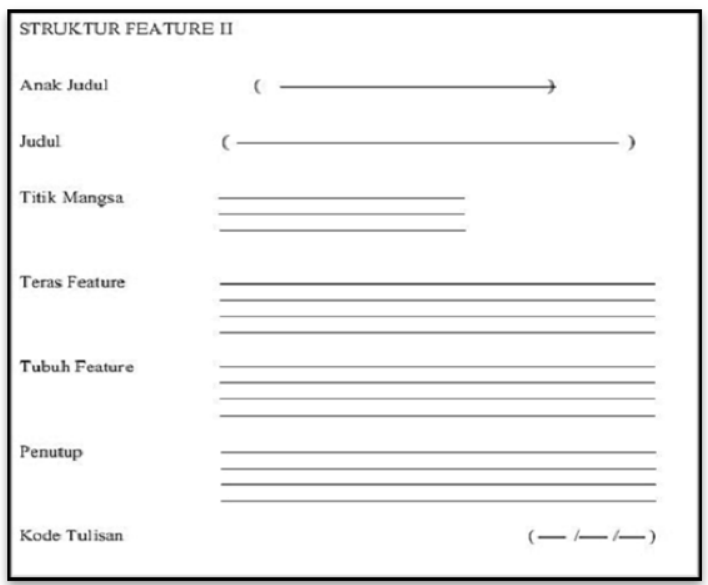

Gambar 3: Struktur Feature II

Struktur feature pada Gambar 2, struktur diawali anak judul, judul, titik mangsa, teras feature, tubuh feature, penutup, dan kode tulisan.

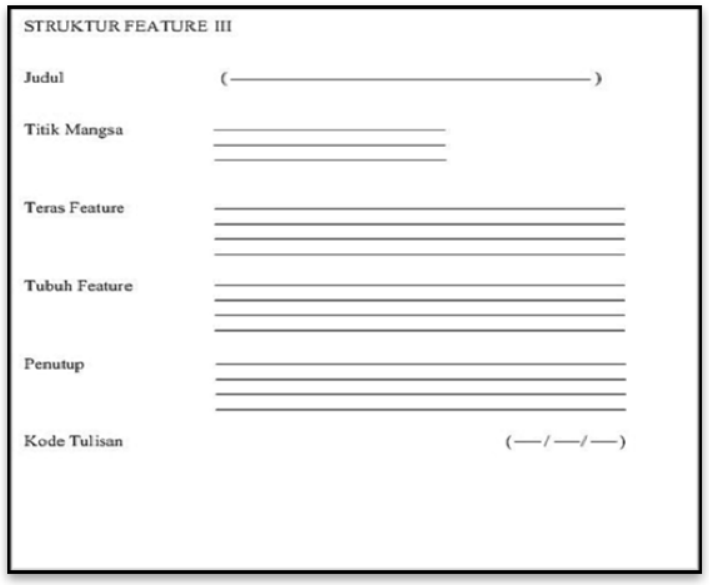

Gambar 4: Struktur Feature III

Pada Gambar 3, struktur feature diawali dengan judul, titik mangsa, teras feature, tubuh feature, penutup, dan kode tulisan.

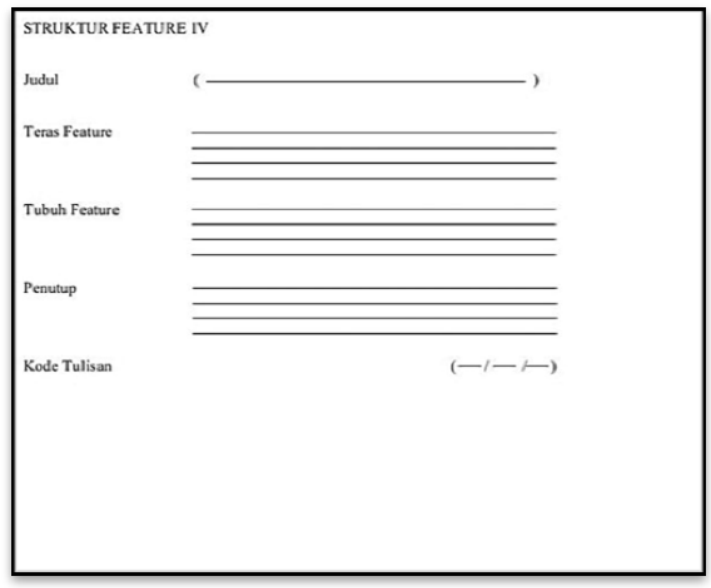

Gambar 5: Struktur Feature IV

Struktur feature pada Gambar 5 diawali dengan judul, teras feature, tubuh feature, penutup, dan kode tulisan.

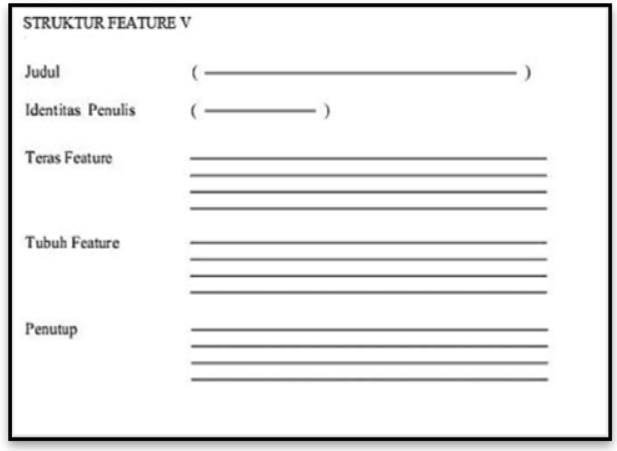

Gambar 6: Struktur Feature V 
Pada Gambar 6, struktur feature diawali judul, identitas penulis, teras feature, tubuh feature, dan penutup.

Latihan dalam bahan ajar meliputi dua macam, yaitu latihan pemahaman teori tentang feature berdasarkan materi yang telah dipelajari dan latihan praktik menulis semua jenis feature. Pemilihan latihan dalam bahan ajar disesuaikan dengan kompetensi yang ingin dicapai, yaitu mahasiswa dapat memahami konsep feature dan menulis feature berdasarkan kaidah yang baik dan benar.Berikut ini disajikan latihan yang terdapat dalam bahan ajar.

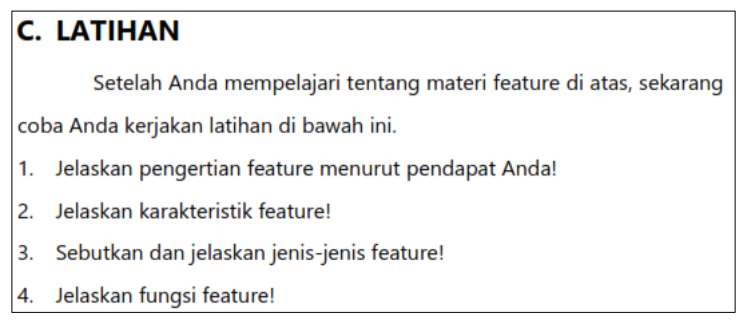

Gambar 7: Latihan Pemahaman Teori Bab 1

Pada Gambar 7, latihan memuat tentang feature meliputi pengertian feature, karakteristik feature, ciri feature, jenis-jenis feature, dan fungsi feature. Latihan ini berfokus pada domain kognitif mahasiswa. Indikator ketercapaian pada latihan bab 1 secara berurutan adalah mahasiswa mampu mendefinisikan feature dengan pendapat sendiri, mahasiswa mampu mengklasifikasikan karakteristik feature, mahasiswa mampu menyebutkan dan memberikan contoh jenisjenis feature, dan mahasiswa mampu menjelaskan fungsi feature.

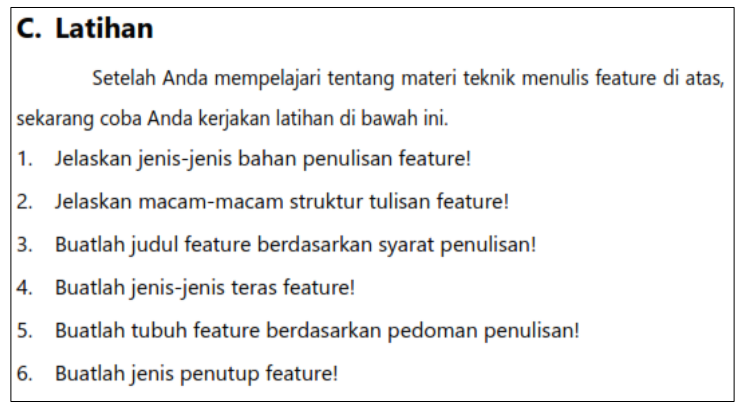

Gambar 8: Latihan Pemahaman Teori Bab 2

Gambar 8 menunjukkan latihan yang disajikan pada bab 2 meliputi bahan penulisan feature, struktur feature, menulis judul feature, menulis titik mangsa feature, menulis teras feature, menulis tubuh feature, dan menulis penutup feature. Fokus dari latihan ini adalah domain kognitif mahasiswa. Indikator ketercapaian pembelajaran secara berurutan adalah mahasiswa mampu menunjukkan jenisjenis bahan penulisan feature, mahasiswa mampu menyebutkan macam-macam struktur tulisan feature, mahasiswa mampu memberikan contoh judul feature, mahasiswa mampu memberikan contoh teras feature, mahasiswa mampu memberikan contoh tubuh feature, dan mahasiswa mampu memberikan contoh penutup feature.

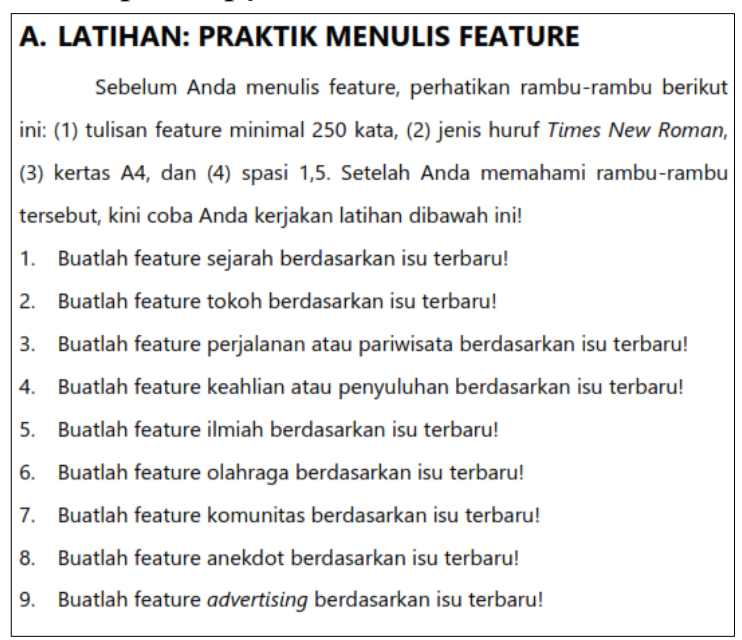

Gambar 9: Latihan Praktik Bab 3

Pada bab 3 disajikan latihan praktik meliputi menulis feature sejarah, menulis feature tokoh, menulis feature perjalanan atau pariwisata, menulis feature keahlian atau penyuluhan, menulis feature ilmiah, menulis feature olahraga, menulis feature komunitas, menulis feature anekdot, dan menulis feature advertising. Latihan ini berfokus pada domain psikomotorik mahasiswa, yakni ketrampilan menulis feature. Indikator ketercapaian pembelajaran dilihat dari bagaimana mahasiswa mampu menulis feature secara baik dan benar.

\section{Sistematika Penyajian Bahan Ajar}

Sistematika penyajian dalam bahan disesuaiakan dengan tingkat pendidikan pengguna. Sistematika penyajian buku pada 
pendidikan tinggi menggunakan pendekatan isi dan disiplin ilmu serta lebih memberikan penekanan pada pesan/bahan atau subtansi keilmuan (Sitepu, 2012). Berdasarkan pendapat Sitepu, bahan ajar ini disajikan dengan prinsip-prinsip instruksional, memberi penekanan pada pesan, dan konsisten. Sistematika penyajian bahan ajar meliputi bagian awal, terdiri atas kata pengantar, daftar isi, dan pendahuluan; bagian inti, terdiri atas bab 1 dengan judul Feature, bab 2 dengan judul Teknik Menulis Feature, dan bab 3 dengan judul Praktik Menulis Feature; dan bagian penutup, terdiri atas daftar pustaka dan lampiran.

Bagian awal bahan ajar mencakup kata pengantar, daftar isi, dan pendahuluan. Pertama, kata pengantar memegang peranan penting dalam bahan bahan ajar. Bagian ini memberikan penjelasan dan informasi secara umum tentang bahan ajar. Oleh karena itu, bagian ini harus disajikan secara menarik. Hal itu bertujuan menarik minat pembaca untuk mempelajari bahan ajar lebih lanjut. Kedua, daftar isi merupakan bagian terpenting dalam buku teks. Daftar isi berguna untuk membatu pengguna dalam pemakaian bahan ajar. Bagian ini memberikan petunjuk pokok isi buku beserta nomor halaman. Ketiga, pendahuluan menjelaskan tentang tujuan umum penggunaan bahan ajar. Bagian ini meliputi tujuan umum buku dan struktur materi pokok. Tujuan umum buku menjelaskan tentang kompetensi yang ingin dicapai. Struktur materi pokok menjelaskan penyajian materi pokok dalam bahan ajar.

Bagian inti bahan ajar meliputi bab 1 dengan judul Feature, bab 2 dengan judul Teknik Menulis Feature, dan bab 3 dengan judul Praktik Menulis Feature. Pertama, bab 1 memaparkan tentang konsep feature. Bagian ini terdiri atas tujuan pembelajaran, materi pembelajaran, dan latihan. Kedua, bab 2 memaparkan tentang teknik menulis feature. Bagian ini terdiri atas tujuan pembelajaran, materi pembelajaran, dan latihan. Ketiga, bab 3 berisi tentang latihan praktik menulis feature dan pedoman penilaian tulisan feature. Latihan praktik menulis feature meliputi feature sejarah, feature tokoh, feature perjalanan atau pariwisata, feature keahlian atau penyuluhan, feature ilmiah, feature olahraga, feature komunitas, feature anekdot, dan feature advertising. Pedoman penilaian digunakan sebagai rambu-rambu penilaian tulisan feature.

Bagian penutup bahan ajar meliputi daftar pustaka dan lampiran. Pertama, daftar pustaka merupakan bagian penulisan bahanbahan pustaka yang digunakan dalam penulisan bahan ajar. Daftar pustaka dalam bahan ajar ini ditulis secara konsisten dan urut. Selain itu, bahan pustaka yang digunakan dalam bahan ajar ini berasal dari sumbersumber yang valid. Kedua, lampiran dalam bahan ajar ini berupa penjabaran pedoman penilaian pada bab 3. Pedoman penilaian ini berisi aspek-aspek yang dinilai dan patokan skor.

\section{Penggunaan Bahasa dalam Bahan Ajar}

Penggunaan bahasa dalam bahan ajar memerhatikan dua aspek, yaitu aspek komunikatif dan aspek penulisan. Aspek komunikatif yang dimaksud adalah bahasa yang digunakan dalam bahan ajar mudah dipahami dan dimengerti oleh pengguna.

Aspek penulisan adalah bahasa yang digunakan dalam bahan ajar memerhatikan penggunaan bahasa Indonesia yang sesuai dengan ejaan, tanda baca, dan tingkat pendidikan pengguna, yaitu mahasiswa. Hal tersebut sesuai dengan pendapat Widodo dan Jasmadi, yaitu setiap intruksi dan paparan informasi yang tampil bersifat membantu dan bersahabat dengan pemakainya, termasuk kemudahan pemakai dalam merespons dan mengakses sesuai dengan keinginan (Lestari, 2013).

Penggunaan bahasa dalam bahan ajar disesuaikan dengan tingkat pendidikan pengguna, yaitu mahasiswa dan dosen. Hal ini dimaksudkan untuk menjelaskan teori dan petunjuk instruksional dalam bahan ajar dapat dipahami oleh pengguna. 


\section{Organisasi Tampilan Bahan Ajar}

Tampilan bahan ajar didesain menarik dan sistematis. Selain itu, tampilan bahan ajar juga disesuaikan dengan tingkat pendidikan pengguna. Hal itu sejalan dengan dengan pendapat Widodo dan Jasmadi, bahan ajar adalah seperangkat seperangkat atau alat pembelajaran berisikan materi pembelajaran yang didesain secara sistematis dan menarik (Lestari, 2013).

Ilustrasi dan gambar merupakan salah satu komponen terpenting dalam bahan ajar. Kemenarikan bahan ajar dapat terlihat dari tampiannya. Tampilan bahan ajar perlu disesuaikan dengan tingkat pendidikan pengguna, yaitu mahasiswa. Berdasarkan hal tersebut, tampilan bahan ajar disesuaikan dengan tingkat pendidikan perguruan tinggi.

Tampilan bahan ajar ini memerhatikan empat aspek. Aspek-aspek tersebut meliputi sampul, tata letak, jenis huruf, dan ukuran huruf. Masing-masing aspek dijelaskan sebagai berikut.

Pertama, sampul adalah bagian pertama yang berguna untuk menarik perhatian pengguna atau pembaca. Sampul bahan ajar didesain untuk menarik minat pembaca. Komposisi warna pada sampul bahan ajar didominasi warna cokelat. Secara visual, sampul bahan ajar dapat dilihat pada gambar di bawah ini.

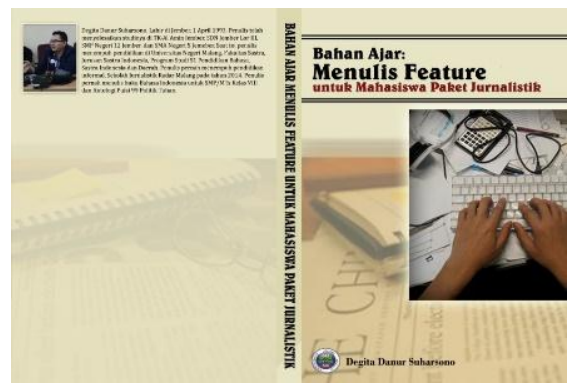

Gambar 10: Sampul Bahan Ajar

Kedua, tata letak bahan ajar memerhatikan tiga aspek, yaitu bidang cetak atau ukuran bahan ajar, margin, dan spasi yang digunakan dalam bahan ajar. Bidang cetak atau ukuran bahan ajar adalah B5 $(18,2 \mathrm{~cm} \mathrm{x}$ $25,7 \mathrm{~cm})$. Pemilihan ukuran bidang cetak bertujuan untuk mudah dibawa oleh pengguna. Pemilihan ukuran bidang cetak tersebut mengacu kepada kaedah format UNESCO, yaitu bidang cetak buku yang baik dengan ukuran minimal $15,5 \mathrm{~cm} \times 23 \mathrm{~cm}$ (Legowo, 2011).

Tata letak juga memerhatikan proporsi margin sebagai berikut: margin atas $3 \mathrm{~cm}$, margin kiri $3 \mathrm{~cm}$, margin kanan $2 \mathrm{~cm}$, dan margin bawah $2 \mathrm{~cm}$. Spasi yang digunakan dalam bahan ajar dibagi menjadi dua, yaitu spasi untuk penjabaran materi dan contoh tulisan feature yang terdapat dalam bahan ajar. Spasi untuk penjabaran materi menggunakan spasi 1.5, sedangkan spasi singel untuk contoh tulisan feature.

Bahan ajar ini juga memerhatikan sistem penomoran. Sistem penomoran yang digunakan dalam bahan ajar adalah bottom of page. Bottom of page adalah sistem penomoran yang terletak pada bagian tengah bawah halaman. Sistem penomoran dalam bahan ajar ini konsisten.

Ketiga, jenis huruf yang digunakan dalam bahan ajar adalah gisha. Ada dua jenis huruf yang cocok untuk digunakan buku cetak, yaitu serif dan sans serif. Jenis huruf serif memiliki sebuah gambaran berupa kaki kecil dan hiasan di ujung atau pangkal setiap hurufnya, sedangkan jenis huruf sans serif tidak memiliki sebuah gambaran berupa kaki kecil dan hiasan di ujung atau pangkal setiap hurufnya (Sitepu, 2012). Pemilihan huruf gisha berdasarkan jenis huruf sans serif, yaitu tidak memiliki garis kecil pada setiap akhir huruf.

Keempat, ukuran huruf dalam setiap bagian bahan ajar ini disajikan berbeda. Ukuran huruf pada setiap judul bagian dan bab adalah 18 pt. Ukuran huruf pada subbagian dan subbab adalah 14 pt. Ukuran huruf yang digunakan untuk memaparkan materi pembelajaran adalah $12 \mathrm{pt}$.

\section{KESIMPULAN}

Materi bahan ajar layak untuk diimplementasikan. Setelah melalui tahap revisi, isi bahan ajar meliputi aspek teori 
(feature dan teknik menulis feature, contoh (tulisan feature, struktur feature, judul feature, titik mangsa, teras feature, dan penutup feature), latihan (latihan pemahaman konsep dan tugas praktik menulis feature), dan pedoman penilaian. Isi bahan ajar telah disesuaikan dengan tujuan kompetensi yang wajib dicapai oleh mahasiswa program jurnalistik dalam mata kuliah Menulis Berita dan Feature.

Sistematika penyajian bahan ajar ini layak untuk diimplementasikan. Sistematika penyajian bahan ajar dibagi menjadi bagian awal, inti, dan penutup. Bagian awal, terdiri atas kata pengantar, daftar isi, dan pendahuluan. Bagian inti, terdiri atas bab 1 dengan judul "Feature", bab 2 dengan judul "Teknik Menulis Feature", dan bab 3 dengan judul "Praktik Menulis Feature". Bagian penutup, terdiri atas daftar pustaka dan lampiran.

Penggunaan bahasa dalam bahan ajar ini memerhatikan dua aspek, yaitu aspek komunikatif dan penulisan. Aspek komunikatif adalah bahasa dalam bahan ajar mudah dipahami oleh pengguna, sedangkan aspek penulisan adalah penulisan dalam bahan ajar memerhatikan ejaan dan tanda baca. Dengan demikian, penggunaan bahasa dalam bahan ajar ini telah layak untuk diimplementasikan.

Tampilan bahan ajar ini layak untuk diimplementasikan. Tampilan bahan ajar meliputi sampul bahan ajar, tata letak, jenis huruf, dan ukuran huruf. Sampul bahan ajar didominasi warna coklat dengan pemilihan ilustrasi gambar yang disesuaikan dengan tingkat pendikan pengguna (mahasiswa dan dosen). Tata letak bahan ajar meliputi ukuran bidang cetak yaitu B5 $(18,2 \mathrm{~cm}$ x $25,7 \mathrm{~cm})$, proporsi margin dalam bahan ajar (margin atas $3 \mathrm{~cm}$, margin kiri $3 \mathrm{~cm}$, margin kanan $2 \mathrm{~cm}$, dan margin bawah $2 \mathrm{~cm}$ ), jenis huruf dalam bahan ajar menggunakan jenis huruf gisha, dan ukuran huruf dalam bahan ajar (judul bagian dan bab $18 \mathrm{pt}$, subbagian dan subbab $14 \mathrm{pt}$, dan untuk memaparkan isi bahan ajar 12 pt).

\section{UCAPAN TERIMA KASIH}

Penulis mengucapkan terima kasih kepada tim ahli bahan ajar dari Jurusan Sastra Indonesia, Fakultas Sastra, Universitas Negeri Malang yang telah memvalidasi bahan ajar yang dikembangkan dan mahasiswa program jurnalistik yang telah bersedia menjadi subjek penelitian.

\section{REFERENSI}

Barus, S. W. (2010). Jurnalistik: petunjuk teknis menulis berita. Jakarta: Erlangga, 26, 43-44.

Dyah, I. A. (2009). Penggunaan Gaya Bahasa Feature Humant Interest Surat Kabar Jawa Pos Edisi" Pengalaman CEO Dahlan Iskan Ganti Liver (26 Agustus-26 September 2007). SKRIPSI Jurusan Sastra Indonesia-Fakultas Sastra UM.

Legowo, B. (2011). Bahan Ajar: Satu Ukuran Profesialisme Dosen Dalam Proses Pembelajaran. Online: Tersedia Di Http://Legowo. Staff. Uns. Ac. Id/, Diakses Tanggal, 19.

Lestari, I. (2013). Pengembangan bahan ajar berbasis kompetensi. Padang: Akademia Permata, 1.

Mbulu, J. (2004). Suhartono. Pengembangan Bahan Ajar, Malang: Elang Mas.

Muslich, M. (2010). Text book writing: Dasardasar pemahaman, penulisan, dan pemakaian buku teks. Jogjakarta: ArRuzz Media, 52, 47-52.

Nasional, D. P. (2008). Materi Pelatihan Kurikulum Tingkat Satuan Pendidikan (KTSP). Jakarta, Depdiknas.

Nuryani, L. (2010). Pemanfaatan media feature untuk meningkatkan keterampilan menulis puisi siswa kelas XI MAN Malang II Batu. Pemanfaatan Media Feature Untuk Meningkatkan Keterampilan Menulis Puisi Siswa Kelas XI MAN Malang II Batu/Leny Nuryani.

Sitepu, B. P. (2012). Penulisan Buku Teks Pelajaran, Bandung: PT. Remaja Rosdakarya.

Sukmadinata, N. S. (2008). Metode Penelitian Pendidikan. Bandung. PT Remaja Rosdakarya.

Syahid, A. (2003). Pengembangan Bahan Ajar Mata Kuliah Rancangan Pembelajaran dengan Menerapkan Model Elaborasi. Universitas Negeri Malang. 
D. D. Suharsono / Jurnal Kiprah 8 (1) (2020) 27-37

Yusufrani, S. C., Nursih, I., \& Prasetya, T. I. (2013). ANALISIS WACANA FEATURE HUMAN INTEREST PADA KORAN
HARIAN UMUM RADAR BANTEN (edisi 15 Juli 2012-15 Agustus 2012). Universitas Sultan Ageng Tirtayasa. 